\title{
Nowy — stary rytuał językowy dziennikarzy sportowych
}

\section{Założenia wstępne}

Pojęcie rytuału należy do tych terminów, które cieszą się w humanistyce dużą popularnością, szeroki jest też zakres jego użycia. Wydaje się, że coraz częściej słowo to ulega pewnej degradacji, traci swą wyjątkowość na rzecz powszechności. Słownik języka polskiego wskazuje na trzy odcienie znaczeniowe rytuału: ,a) zespół czynności stanowiący ustaloną formę zewnętrzną społecznie doniosłego aktu, uroczystości, ceremonii; b) ustalona forma zabiegów magicznych lub praktyk religijnych; ceremonia; c) przen. zespół powtarzalnych zwyczajowych czynności towarzyszących codziennym, zwykłym wydarzeniom" (USJP 2003), tymczasem słowo to coraz rzadziej łączy się z antropologicznym, uwarunkowanym zazwyczaj kulturowo i religijnie postrzeganiem zjawisk. W języku potocznym stało się w pewnym stopniu synonimem rutyny, powtarzalności, schematu. Ciekawie na tym tle prezentuje się swoisty termin, za jaki należy uznać rytuat językowy.

$\mathrm{W}$ artykule poświęconym pojęciu rytualności w zachowaniach językowych Stanisław Gajda przedstawił następującą konkluzję: „Rytualizmy od niedawna zwróciły na siebie uwagę językoznawców. Nic więc dziwnego, że istnieją rozbieżności w wyznaczaniu ich zakresu i w przypisywanych im własnościach. Można uznać to za naturalny etap w rozwoju wiedzy o nich" (Gajda 2004, s. 16). W niniejszym artykule chciałabym skupić się na rytuale językowym rozumianym dość wąsko. W literaturze przedmiotu odnaleźć możemy m.in. następującą definicję tego terminu: „działanie językowe lub/i pozajęzykowe o następujących cechach konstytutywnych: 1) charakter instytucjonalny — oznacza postępowanie według określonych wzorów; 2) charakter społeczny — działanie odbywające się w grupie i zorientowane na daną grupę społeczną; 3) powtarzalność — regularność 
użycia w tych samych sytuacjach; 4) kontekst motywacyjny — rytuał jest motywowany przez pewien sens, który ma konserwować oraz przez wartości, które ma chronić" (Małyska 2004, s. 18). W dalszej części wywodu autorka definicji zwraca uwagę na pewne przesunięcie interpretacyjne rytuału w zakresie komunikacji społecznej — w jej obrębie „pojawiają się specyficzne sytuacje, które z uwagi na wysoką powtarzalność, są wysoce przewidywalne. Stąd też ową komunikację cechuje tendencja do rytualizacji zachowań. Przestrzeganie rytuału jest niezbędne dla osiągnięcia komunikacyjnej skuteczności” (Małyska 2004, s. 21). Badaczka zwraca także uwagę na pewne pokrewieństwo w tym zakresie terminu rytuat i etykieta językowa (por. Małyska 2004, s. 22).

Zanim odniosę się do zaprezentowanych stanowisk, chciałabym krótko scharakteryzować materiał badawczy, który stanowi podstawę poczynionych w dalszej części obserwacji. Otóż, przedmiotem badań uczyniłam teksty bezpośrednich relacji telewizyjnych z meczów piłkarskich z lat siedemdziesiątych XX wieku oraz tych pochodzących z ostatnich lat, tj. 2010-2014 ${ }^{1}$. Traktuję widowisko sportowe jako pewien rytuał, w którym widz może uczestniczyć bądź bezpośrednio, na stadionie, w hali, bądź pośrednio jako odbiorca przekazu medialnego (w tym przypadku - telewizyjnego). Uważam, że jest to wydarzenie o charakterze rytualnym, gdyż wywołuje określone sekwencje zachowań zarówno po stronie uczestników, jak i widzów, tworzy specyficzną ceremonię opartą na określonych zasadach i, co najważniejsze, w przekazie medialnym łączy się z rytualizacją językową. Zatrzymajmy się zatem na chwilę nad kwestią medialnego rytuału sportowego.

\section{Widowisko sportowe jako rytuał}

W zacytowanej wcześniej definicji słownikowej rytuału wyeksponowany został aspekt zewnętrznej formy wobec ceremonii, uroczystości. Za rodzaj tej ostatniej uznać należy wydarzenie medialne definiowane jako „uroczystość, która stanowi wyłom w codzienności, której uświęcone treści traktowane są z namaszczeniem, a oddana widownia czynnie w niej uczestniczy" (Dayan, Katz 2008, s. 54). I rzeczywiście, rytuał telewizyjny rozpoczyna się kilkanaście minut przed rozpoczęciem transmisji. Jak pisze Wiesław Godzic: „porządkujesz stolik przed telewizorem: chcesz, żeby zniknęły resztki jedzenia i przygotowujesz nowe porcje herbat, soków i ciasteczek. Zagarniasz pozostałych użytkowników przed ekran, przekonując przy użyciu różnych metod, że za chwilę będzie się działo wszystko to, czego jako Polak, Anglik, Czech — jako Człowiek i/lub Obywatel — przegapić nie możesz i nie powinieneś [...]; może nawet zaprosisz sąsiada albo włożysz odświętną koszulę" (Godzic 2008). Autorzy koncepcji wydarzenia

${ }^{1}$ Przykłady zaprezentowane w tekście pochodzą jedynie z dwóch meczów, jednak poczynione obserwacje odnoszą się do znacznie szerszego materiału badawczego. 
medialnego, Daniel Dayan i Elihu Katz, podkreślają, że są to obrzędy przychodzenia i odchodzenia. „Główne postaci dokonują rytualnych wejść w uświęconą przestrzeń, a jeśli los się do nich uśmiechnie, dokonują także rytualnych powrotów. Podstawą tych form dramaturgicznych jest obrzęd przejścia, polegający na tym, że postać odrywa się od rzeczywistości, wchodzi w fazę liminalną, gdzie jest w rozmaity sposób doświadczana i nauczana, a następnie wraca do normalnego społeczeństwa [...]" (Dayan, Katz 2008, s. 190). Badacze wskazują na trzy typy wydarzeń medialnych o charakterze rytualnym, a mianowicie na Konkursy, Konkwisty i Koronacje.

Dla niniejszych rozważań najistotniejsza jest pierwsza grupa, Konkursy, wśród których znajdują się zawody sportowe. Truizmem jest stwierdzenie, że przyciągają one miliony widzów zarówno na stadiony, jak i przed telewizory. Udział w nich staje się świętem, celebracją, rytuałem, który należy odpowiednio przeprowadzić. W zakresie bezpośredniego uczestnictwa w zawodach za elementy rytualne można uznać wejście zawodników na stadion czy odegranie hymnów narodowych. Kiedy jednak mowa o uczestniku zapośredniczonym, bo tak określiłabym widza transmisji sportowej, rytuał przybiera nieco inny charakter, a swoistym mistrzem ceremonii staje się dziennikarz, który prowadzi relację $e^{2}$.

\section{Dziennikarz jako mistrz ceremonii}

Kiedy widz zasiada przed telewizorem, aby obejrzeć transmisję meczu, ma do dyspozycji obraz, jaki proponuje mu realizator, oraz relację/komentarz ${ }^{3} \mathrm{dzien}$ nikarza. Są, co prawda, tacy, którzy próbują oglądać zawody sportowe, wyciszając przy tym fonię, jednak zdecydowana większość uczestników telewizyjnego rytuału wsłuchuje się w słowa osoby komentującej ${ }^{4}$.

W dalszej części analizie poddane zostaną językowe aspekty rytualizacji transmisji sportowej z dwóch meczów, które dzieli ponad 40 lat. Ich wybór nie był przypadkowy. Oba uznano za wydarzenia historyczne, przełomowe w dziejach

${ }^{2}$ Należy zaznaczyć, że transmisja uznawana jest w niniejszym szkicu za gatunek nadrzędny, swoistą kolekcję, w której skład, poza obrazem, wchodzi m.in. specyficzna narracja prowadzona przez dziennikarza (często w parze z ekspertem), nazywana relacją bądź komentarzem. Aby uniknąć nieporozumień terminologicznych, stosuję termin relacja do nazwania wspomnianej narracji, transmisję zaś definiuję jako połączenie relacji z elementem wizualnym.

3 O ile gatunkowo mamy do czynienia z relacją, o tyle funkcjonalnie oczekujemy raczej komentarza. Tradycyjnie dziennikarza relacjonującego mecz nazywa się komentatorem, czynność zaś - komentowaniem, o czym świadczy choćby ukazujący się na początku większości transmisji napis: komentuje... (tu podane jest imię i nazwisko).

${ }^{4}$ Raz jeszcze odwołam się do cytowanych już przeze mnie wielokrotnie słów: „Czy próbował ktoś obejrzeć mecz bez komentarza? Smakuje jak nieposolona zupa. Jest on nierozerwalną częścią każdego widowiska sportowego. Zwłaszcza ten na żywo, który rozgrywa się tu i teraz, wraz z tym widowiskiem. Taki komentarz pomaga, podkreśla emocje, ale niekiedy też i bawi” (Wpadki 2006, s. 5). 
polskiego futbolu. Pierwszy to mecz Anglia-Polska rozegrany 17 października 1973 roku w Londynie (wynik remisowy 1:1). Drugi to mecz Polska-Niemcy, który odbył się 11 października 2014 roku w Warszawie (wygrana Polski 2:0). Oba spotkania odbyły się w ramach meczów eliminacyjnych odpowiednio do mistrzostw świata i mistrzostw Europy. Pierwsze transmitowano na antenie Telewizji Polskiej, a komentował je Jan Ciszewski. Drugie pojawiło się w stacji komercyjnej Polsat, a komentatorami byli dziennikarz Mateusz Borek oraz były piłkarz Tomasz Hajto.

Już ta pobieżna charakterystyka obu transmisji wskazuje na istotną różnicę w ich przebiegu. W przypadku pierwszej mistrz ceremonii był tylko jeden (Jan Ciszewski). W drugiej rolę tę odgrywają dwie osoby — dziennikarz i komentator, przy czym Mateusza Borka można by uznać za głównego prowadzącego, Tomasza Hajtę zaś za wspierającego ${ }^{5}$. Z punktu widzenia rytualizacji jest to dość znaczna różnica, prowadzenie narracji ${ }^{6}$ przez jedną osobę pozostawia bowiem wyłącznie w jej gestii budowanie napięcia, podgrzewanie emocji. Jeśli dwie osoby komentują wydarzenia na boisku, to wówczas mogą wchodzić w dialog zarówno z widzami, jak i między sobą, co pozornie ułatwia celebrowanie meczu (łatwiej budować nastrój), jednocześnie jednak może spowodować nadmierne rozdialogizowanie relacji, czyli zbyt częste prowadzenie rozmów między dziennikarzem i ekspertem, które dzieją się poza widzem, a tym samym powodują jego zniechęcenie, a nawet rezygnację z oglądania meczu.

W relacji meczu Polska-Niemcy, mimo narracji dwuosobowej, widać wyraźny podział ról. To dziennikarz jest elementem nadrzędnym i to on prowadzi widza przez spotkanie, ekspert zaś stara się ograniczać swój udział do fachowych komentarzy.

Pierwszym momentem konstytutywnym relacji jest powitanie widzów. To początek rytuału grzecznościowego, który, o czym wspominałam wcześniej, nazywamy etykietą językową. W przypadku meczu Anglia-Polska sama formuła powitalna nie była zbyt rozbudowana i właściwie ograniczyła się do tego, co można by nazwać rytuałem językowym, czyli powtarzalną sekwencją: Halo, halo, ze stadionu Wembley w Londynie wita państwa Jan Ciszewski. Wraz z postępem technicznym i udoskonaleniem jakości przekazu wzorzec ten uległ pewnej modyfikacji, zacytowane halo, halo służyło bowiem nie tylko powitaniu, lecz także sprawdzeniu jakości połączenia. Dziś zazwyczaj pojawia się następująca formuła powitalna: Dobry wieczór państwu, ze Stadionu Narodowego w Warszawie mówiq Tomasz Hajto i Mateusz Borek. To dość sztampowe przywitanie widzów poprzedzone jest jednak pewnym wstępem: Czy to jest ten dzień, czy to jest ta noc, kiedy oszukamy historię, kiedy oszukamy przeznaczenie. Stadion Narodowy w Warszawie, jedenasty dzień października 2014 roku, eliminacje Piłkarskich Mistrzostw

\footnotetext{
${ }^{5}$ Szerzej o dwugłosie komentatorskim w (Grochala 2012).

${ }^{6}$ O relacji jako narracji por. (Grochala 2013).
} 
Europy Francja 2016. Polska gra z mistrzami świata, Polska gra z Niemcami. Takiego wstępu pozbawiony jest komentarz Jana Ciszewskiego, jak i wszystkie inne emitowane w XX wieku. Można zatem uznać tę swoistą preambułę za element nowy, ale już włączony do rytuału komentatorskiego. Jego celem jest przede wszystkim zbudowanie napięcia, wprowadzenie w atmosferę spotkania, ukazanie jego wyjątkowości poprzez pewną hiperbolizację, o czym świadczy m.in. użycie określeń oszukiwanie historii, przeznaczenia. Wynika z nich, że dziennikarz zaprasza na swoisty spektakl ezoteryczny, w czasie którego zmienią się dzieje świata, a widzowie zostają włączeni do kręgu osób wtajemniczonych.

Bezpośrednio po powitaniu następuje najczęściej przybliżenie sytuacji meczowej, tzn. podanie wiadomości o stadionie, frekwencji itp. Takich informacji dostarczają nam oba komentarze:

J.C. 7: Proszę państwa, sto tysięcy ludzi na Wembley, sto tysięcy ludzi na słynnym, pięćdziesięcioletnim stadionie Wembley, czterysta milionów przed telewizorami w czternastu krajach świata według ICA, która prowadzi transmisję, powinno oglądać mecz tych dwóch świetnych drużyn.

M.B.: Gigantyczne zainteresowanie tym spotkaniem. Jak zdradził prezes PZPN, Zbigniew Boniek, było ponad milion zapytań o bilety. To warunki, w jakich przyjdzie dziś rywalizować piłkarzom obu reprezentacji, szesnaście stopni, naprawdę ciepły wieczór [...]. Pięćdziesiąt siedem i pół tysiąca kibiców na Stadionie Narodowym, którzy dali już pierwszą próbę swoich możliwości.

Istotna jest w tych fragmentach obecność liczb. Służą one bowiem budowaniu wyjątkowości i poczucia udziału w niesamowitym rytuale. Skoro tyle osób ogląda dany mecz, a ja jestem wśród nich, to rzeczywiście dzieje się coś niecodziennego - tak może pomyśleć niejeden telewidz, a to poczucie bycia wybranym do wzięcia udziału w celebrze spotęguje w nim potrzebę obejrzenia całego meczu. Oczywiście można wyobrazić sobie sytuację, w której dane liczbowe nie padają, gdyż nie są one istotne dla samego meczu, ale jednak element ten został włączony na stałe do kanonu relacji, co świadczy o jego istotnej roli w komentarzu.

Kolejnym elementem wstępu jest prezentacja sytuacji w grupie, ponieważ oba spotkania to mecze eliminacyjne. Tym razem, zwłaszcza w komentarzu sprzed 40 lat, ujawnia się emocjonalność i, co ciekawe, pewna kreatywność w sposobie zaprezentowania układu tabeli:

J.C.: Nie będę przypominał historii spotkań w naszej grupie, gdyż wiadomo wszystkim, że Polska prowadzi, mając jeden punkt przewagi nad gospodarzami. Remis, a spotkamy się w przyszłym roku z Brazylią, Argentyną, Nie-

${ }^{7}$ Wprowadzono następujące skróty dla oznaczenia osoby mówiącej: J.C. — Jan Ciszewski, M.B. - Mateusz Borek, T.H. - Tomasz Hajto. Każdorazowo najpierw pojawia się cytat z meczu z 1973 roku, a potem z 2014. 
miecką Republiką Federalną, słowem, najlepszymi z najlepszych. Mówiąc inaczej, w tej chwili, a więc o godzinie 19.43 jesteśmy w finale, no bo punkt przewagi, ale przed nami jeszcze ten wielki mecz.

M.B.: I to już tabela naszej grupy. Dzisiaj drugie zwycięstwo Irlandii, mają już sześć punktów, dzisiaj pierwsze punkty zdobyli także Szkoci, podobnie jak my, po meczu z Gibraltarem. Wcześniej Niemcy pokonali Szkocję. Bez punktów, po tych pierwszych meczach, Gruzja i Gibraltar.

Prezentacja ogólnej sytuacji meczów eliminacyjnych służy, po pierwsze, poinformowaniu widzów, zwłaszcza tych, którzy przyjęli zaproszenie na ten spektakl, a nie do końca orientują się w zawiłościach rozgrywek piłkarskich. Po drugie, to kolejny rytuał, którego funkcją jest budowanie napięcia — należy zauważyć, że sytuacja $\mathrm{w}$ grupie eliminacyjnej prezentowana jest $\mathrm{w}$ taki sposób, by podnieść rangę komentowanego meczu i uczynić z niego mecz o wszystko, a skoro tak jest, to trzeba go obejrzeć. Poniższe, jakże podobne do siebie cytaty, potwierdzają tezę o budowaniu przez komentatorów atmosfery wyjątkowości meczu:

J.C.: Proszę państwa, trzeba od razu powiedzieć, że będzie to najcięższy mecz naszej drużyny w historii polskiej piłki nożnej. Dla Anglików jest to spotkanie z cyklu to be or not to be $e^{8}$.

T.H.: Trzeba powiedzieć, że mamy dzisiaj ogromną szansę przy tych kontuzjach, przy tych rezygnacjach zawodników, którzy odeszli już z reprezentacji Niemiec, żeby powalczyć o to pierwsze, historyczne zwycięstwo.

W tym miejscu należy zaznaczyć dość istotną różnicę między porównywanymi meczami. Otóż drużyna grająca z Anglią, choć nie uchodziła za faworyta, miała zdecydowanie lepsze notowania niż reprezentacja grająca 40 lat później z Niemcami. Stąd w obu fragmentach pojawia się nadzieja, ale ta z 2014 roku wydaje się mrzonką. Jednak i to zabieg zamierzony, widz staje się bowiem uczestnikiem czegoś nierzeczywistego, wkracza w widowisko magiczne, w którym elementem łączącym wszystkich jest wiara w cud.

Bardzo ważnym momentem meczowego rytuału jest zdobycie bramki. To właściwy cel, do którego dąży się w trakcie całego widowiska, na który czekają widzowie. Komentatorzy dość podobnie prezentują to wydarzenie, zazwyczaj poprzez wielokrotne wykrzyknięcie z widoczną emfazą słowa gol. Schemat ten nie zmienił się przez 40 lat. Nie zmieniła się też treść komentarza, który przede wszystkim podkreśla nieprzeciętny charakter zdobytej bramki, bynajmniej nie $\mathrm{w}$ aspekcie techniki wykonania, lecz pokonania rywala, który postrzegany jest jako drużyna zdecydowanie lepsza ${ }^{9}$ :

${ }^{8}$ Na marginesie warto odnotować, że cytat z Szekspirowskiego Hamleta należy do ulubionych skrzydlatych słów wykorzystywanych przez komentatorów sportowych.

${ }^{9} \mathrm{~W}$ aspekcie psychologicznym można mówić o syndromie Dawida i Goliata — nasza 
J.C.: Lato, w środku mamy dwóch zawodników, Gadocha. Gol, gol, gol. Proszę państwa, sensacja na Wembley. Dziesiąta minuta drugiej połowy. Cudowny wypad polskiej trójki, rozbicie ataku. Grzegorz Lato, ucieka tutaj Gadocha, wyłożenie piłki do Jana Domarskiego i Shilton puszcza pod brzuchem piłkę. Jeden zero dla polskiej drużyny na Wembley. Czterysta milionów ludzi siedzących w tej chwili przed telewizorami przeciera ze zdumienia oczy. Biało-Czerwoni prowadzą w Londynie, stolicy Anglii z mistrzem świata z roku 1966 jeden zero.

M.B.: W polu karnym Milik, Lewandowski i gol, gol. Arkadiusz Milik. Jeden do zera dla Biało-Czerwonych w pięćdziesiątej drugiej minucie. Arek Milik [...]. Tak, to jest prawda. W pięćdziesiątej drugiej minucie na Stadionie Narodowym w Warszawie Polska prowadzimy z Niemcami jeden do zera.

M.B.: Lewandowski, Mila, jest szansa. Gol, gol, gol! Polska dwa, Niemcy zero. Już nam nikt tego zwycięstwa nie wydrze. Euforia na Narodowym. Polacy wygrywają $z$ Niemcami dwa do zera ${ }^{10}$.

Ostatnim, stałym elementem rytuału jest zakończenie. Komentator dokonuje podsumowania meczu, żegna się z widzami i kończy widowisko. Fragmenty te cechuje duża emocjonalność, nie tylko w sytuacji wygranej, co pokazują poniższe cytaty, ale także po przegranym spotkaniu ${ }^{11}$, kiedy to rozpatruje się przyczyny nieudanego widowiska. Dziennikarz zrzuca wówczas odpowiedzialność na piłkarzy, trenerów, działaczy, a sam jednoczy się z widzami w poczuciu rozgoryczenia.

Powróćmy jednak do analizowanych meczów, a te zakończyły się sukcesem. W obu relacjach wyeksponowany zostaje fakt zwycięstwa (także wtedy, gdy formalnie padł remis) nad mistrzami świata. Co ciekawe, w przypadku meczu z 1973 roku Anglicy to nie aktualni królowie globu, lecz mistrzowie sprzed siedmiu lat. Widać tu jednak wyraźnie funkcję magiczną takich sformułowań jak pokonanie mistrzów świata - ich rolą jest zarówno uwydatnienie zwycięstwa, jak i nadanie całemu wydarzeniu charakteru wyjątkowości:

J.C.: Rok temu ze stadionu olimpijskiego w Monachium mówiłem: Dwadzieścia lat czekałem na ten historyczny moment, ten historyczny sukces. Proszę państwa, tylko rok czekałem do największego tryumfu w historii polskiego futbolu. Biało-Czerwoni walczą fantastycznie od pierwszych sekund do końca sprawcami największej sensacji w historii światowego futbolu. Re-

drużyna, skazana na niepowodzenie, pokonuje giganta.

10 W meczu z 1973 roku Polacy strzelili tylko jedną bramkę, w roku 2014 zaś dwie, stąd obecność dwóch cytatów z roku 2014, a tylko jednego z 1973.

11 Komentarzem, w którym ten element szczególnie się uwidocznił, była relacja z meczu Słowenia-Polska rozegranego 9 września 2009 roku, przegranego przez naszą drużynę trzema bramkami. Dariusz Szpakowski pod koniec meczu nie komentował już wydarzeń na boisku, lecz wygłosił długi monolog, w którym negatywnie ocenił trenera reprezentacji, Leo Beenhakkera. 
prezentacja Anglii, mistrz świata z roku 1966 zaledwie zremisowała na własnym stadionie, w obecności stu tysięcy widzów i w obecności czterystu milionów sympatyków piłki nożnej na całym świecie, jeden jeden. Złotą bramkę strzelił Jan Domarski, wyrównał Allan Clarke. Brawo Polska, brawo Polska i jeszcze raz brawo Polska. Hamlet kiedyś powiedział The rest is silence — Reszta jest milczeniem. Reszta jest milczeniem dla Anglii, a dla Polski i polskiego futbolu wszystko. Dziękuję drodzy, kochani państwo, bardzo dziękuję. Och, proszę mi wybaczyć. Już tylko powiem swoje tradycyjne do usłyszenia. Z Londynu mówił Jan Ciszewski.

M.B.: Prawdopodobnie spełnią się nasze marzenia [...]. Sekundy do końca [...]. Koniec, koniec, koniec. Wygrywamy z mistrzem świata dwa do zera. To się dzieje na naszych oczach. To jest prawda. Arkadiusz Milik i Sebastian Mila. Polska ma po dwóch rundach eliminacji Euro 2016 sześć punktów. A Joachim Löw, on jeszcze jest w szoku, jeszcze tutaj gra ten mecz [...]. Szalona radość polskiego zespołu. Dzisiaj tutaj były fragmenty, kiedy się ta gra nie układała, kiedy lepsi byli Niemcy. Ale był zespół, była determinacja, była ambicja [...]. Wygrywamy dwa do zera i mamy już za sobą dwa kroki w drodze do finałów mistrzostw Europy [...]. Interesuje nas to, że dzisiaj po raz pierwszy w historii pokonaliśmy Niemców, którzy przyjechali do Warszawy jako mistrzowie świata. Przeżyliśmy z państwem magiczną noc. Dwa do zera dla Biało-Czerwonych. No, nie pójdzie dzisiaj Warszawa długo spać ${ }^{12}$. Dziękują państwu Tomasz Hajto i Mateusz Borek. Halo studio.

\section{Podsumowanie}

Analizowane mecze dzieli ponad 40 lat, wydaje się jednak, że w cytowanych komentarzach oddziennikarskich nie widać tego upływu czasu, choć rzeczywistość, zwłaszcza ta związana z mediami, uległa licznym przeobrażeniom. Mecz na Wembley rozegrany został w dobie paleo-telewizji, na Stadionie Narodowym zaś w rozkwicie neo-telewizji ${ }^{13}$. Spotkanie w Anglii to czas monopolu telewizji publicznej, a mecz w Warszawie przypada na okres bardzo dużej konkurencyjności, komercjalizacji mediów i walki o widza.

Nasuwa się pytanie, dlaczego w tekście komentarza nie widać upływu tych 40 lat. Wszak przy jakimkolwiek innym programie telewizyjnym, choćby serwisie informacyjnym, różnice są widoczne natychmiast. Sądzę, że powodem jest samo widowisko sportowe ujmowane jako rytuał. Zasady uczestnictwa w obrzę-

12 Słowa te podkreślają wspólnotowość, zachęcają telewidzów do wspólnego, dalszego świętowania zwycięstwa.

13 Oba terminy (paleo- i neo-telewizja) stosuję za (Casetti, Odin 2004). 
dzie nie zmieniają się bowiem zbyt szybko, a pewną stabilizację uznać należy za jego cechę konstytutywną. Dziennikarze mają świadomość bycia mistrzem ceremonii, zdają sobie sprawę z tego, że widzowie nie oczekują od nich nowatorstwa. Chcą, by poprowadzić ich przez mecz jak przez nabożeństwo, w którym stale powtarza się te same formuły. Czy to oznacza zatem, że w relacji nic się nie zmienia? Nic bardziej mylnego. Przykładem nowości jest już sama narracja dwuosobowa w opozycji do wcześniejszej jednoosobowej. Innych dowodów dostarczyłaby dokładna analiza całej relacji, w której współcześnie często nie tyle liczy się to, co dzieje się na boisku, ile osobowość dziennikarza i eksperta, pragnących przykuć uwagę widza, a jednocześnie wypromować siebie (por. Grochala 2013). Niezmienne pozostają kluczowe momenty, do których należą: powitanie widzów, rozbudowany wstęp do meczu, momenty strzelenia bramek oraz zakończenie, czyli chwile najbardziej celebrowane.

\section{Bibliografia}

Casetti F., Odin R. (2004), Od paleo- do neo-telewizji. W perspektywie semiopragmatyki, [w:] Po kinie?..., red. A. Gwóźdź, Kraków, s. 117-136.

Dayan D., Katz E. (2008), Wydarzenie medialne. Historia transmitowana na żywo, Warszawa.

Gajda S. (2004), Rytualność i kreatywność w zachowaniach językowych, [w:] Rytualizacja w komunikacji spotecznej i interkulturowej, red. J. Mazur, Lublin, s. 11-16.

Godzic W. (2008), Ceremonia na ekranie — koniec wojen w pokoju telewizyjnym, [wstęp do wydania polskiego w:] D. Dayan, E. Katz, Wydarzenie medialne. Historia transmitowana na żywo, Warszawa, s. 5-32.

Grochala B. (2012), Dwugłos dziennikarsko-ekspercki - wpływ czynników pragmatycznych na sposób konstruowania komentarza sportowego/relacji sportowej na żywo, [w:] Akty i gatunki mowy w perspektywie kulturowej, red. A. Burzyńska-Kamieniecka („Język a Kultura” 23), Wrocław, s. 199-210.

Grochala B. (2013), Komentarz sportowy jako narracja, [w:] Narracyjność języka i kultury, red. D. Filar, D. Piekarczyk, Lublin, s. 237-246.

Małyska A. (2004), Pojęcie rytuału na tle innych zjawisk językowych, [w:] Rytualizacja w komunikacji społecznej i interkulturowej, red. J. Mazur, Lublin, s. 17-24.

USJP (2003), Uniwersalny stownik języka polskiego, red. S. Dubisz, Warszawa.

Wpadki (2006), Wpadki komentatorów czyli stońce zachodzi za wschodnia trybuna stadionu..., oprac. J. Łuczak, R. Nawrot, Poznań.

\section{A new - old language ritual of sports journalists}

\section{Summary}

Sports event is a kind of media event in which the audience participates both in the stadium and in front of TV screens. The master of ceremonies is a journalist. He leads the audience through the match and the important means of ceremony is language. The article compares the ways of celebration in two 
games. The first is the England v. Poland match at Wembley in October 1973, ended with a 1:1 draw, which gave the Poles advancment to the World Cup. The second is the historical, because first, Polish national football victory over Germany in October of 2014 at the National Stadium in Warsaw. The analysis shows, that there are no important differences between both sports commentaries.

Keywords: sports event, sports commentary, language ritual, sports journalist 